\title{
Emotional intelligence and its influence on the adaptive skills of children with hearing disabilities
}

Cristina Bălaș-Baconschi, Lucreția-Delia Dobrican 


\title{
Emotional intelligence and its influence on the adaptive skills
}

\section{of children with hearing disabilities}

\author{
Cristina Bălaș-Baconschi ${ }^{a^{*}}$, Lucreția-Delia Dobrican ${ }^{\mathrm{b}}$ \\ ${ }^{a}$ Special Education Department, Babeș-Bolyai University, 7 Sindicatelor Street, 400029, Cluj-Napoca, Romania \\ ${ }^{b}$ Special Technological High School for Hearing Impaired, 40 Dorobantilor Street, 400117, Cluj-Napoca, Romania
}

*Corresponding author: maria.balas@ubbcluj.ro

\section{Abstract}

Keywords: emotional intelligence, adaptive skills, hearing disabilities
As several studies reveal there are strong relationships between emotional intelligence and the academic competences and on the other side, between emotional intelligence and adaptive behavior. The present study aims to demonstrate the relationship between emotional intelligence and adaptive skills, mainly in the social area in children with hearing disabilities. On the other hand, we focused on the relationships that could be established between the type of the disability, the hearing aids and the adaptive skills. Our findings showed that there is no significant correlation between emotional intelligence and adaptive skills and between the adaptive skills in the school setting and the degree of hearing disabilities, as well as the type of prosthesis. These results are there to confirm other findings which emphasize the fact that children with hearing disabilities have about the same social skills as the typically developed and in the same time they have no significant delays regarding the level of socio-emotional adaptability.
Zusammenfasung

\section{Schlüsselworte:}

emotionale Intelligenz, Anpassungsfähigkeit, Gehörsstörungen
Wie zahlreiche Studien erweisen, wird ein enger Zusammenhang zwischen emotionaler Intelligenz und Lernfähigkeit sowie zwischen emotionaler Intelligenz und Anpassungsfähigkeit festgestellt. Vorliegende Studie nimmt sich vor, den Zusammenhang zwischen emotionaler Intelligenz und der Anpassungsfähigkeit, vordergründig im Kontext sozialer Fähigkeiten bei Kindern mit Gehörsstörungen zu beweisen. Auf der anderen Seite haben wir uns auf den Zusammenhang der zwischen dem Typ der Behinderung, der Prothese und der Anpassungsfähigkeit festgestellt werden konnte, konzentriert. Unsere Erkenntis ist, dass es keinen wesentlichen Zusammenhang zwischen emotionaler Intelligenz und der Anpassungsfähigkeit und zwischen der Anpassungsfähigkeit im Unterrichtskontext und der Stärke der Gehörsstörungen sowie der Art der Prothese gibt. Diese Ergebnisse bestätigen andere Erkenntnisse die hervorheben, dass Kinder mit Gehörsstörungen ungefähr die gleichen sozialen Fähigkeiten wie die normal entwickelten haben und gleichzeitig weisen sie keine wesentlichen Verzögerungen bezüglich dem Grad der sozial-emotionalen Anpassungsfähigkeit auf.

\section{Introduction}

As specified by Goleman (2019), some skills facilitate the effectiveness of human interactions and relationships, namely self-assessment and self-identification, self-control and empathy, skills which interfere directly with emotional intelligence. Studies performed in schools and universities showed that students with a higher level of emotional intelligence obtain higher academic achievements than the ones with a lower level of emotional intelligence (Pleșca, 2016). In the same time, there are studies that emphasize the fact that methods used in order to improve emotional intelligence in school settings, family settings could, beside other factors, can compete to a growth of school performance in children.
According to Conners-Burrow et al. (2017) most important emotional skills include: self-awareness, that is the ability to recognize one's emotions, sense of selfefficacy and self-confidence, etc.), self-management (the ability to regulate one's emotions, including controlling impulses, motivating oneself, setting and working toward goals) and social awareness meaning showing empathy and understanding others' perspectives, respect for others).

We may refer also to a study conducted by Raicu (2015) which demonstrate that preadolescents with a high level of emotional intelligence are sociable, can clearly and directly express their feelings, emotions, are easily adapted to stress conditions, make new friends naturally, are independent and self-confident. 
Children learn social and emotional skills beginning in infancy and early childhood. So social-emotional development involves children's growing capacities to recognize and manage their emotions, have positive relationships with adults and peers and solve problems effectively.

At the opposite children without strong social and emotional skills often receive negative feedback from teachers and are rarely praised by teachers for appropriate behavior and are even included in punishing interventions. Without an effective and early intervention, children with social-emotional delays are likely to have problems further on in the next years (Campbell, 1995), including social and academic problems in school, school dropout, and even adolescent and adulthood delinquency (Dunlap et al. 2006). All these concerns are a reality in different schools for children with disabilities, in which the students exhibit disruptive and challenging behavior due to their lack of emotional abilities and strengths. These statements were, partly, the reason for us to try to show how things go for children in schools for hearing disabilities.

\section{Adaptive skills and emotional intelligence}

Adaptive behavior is described as the ensemble of conceptual, social and practical abilities learned and used by one person during his/her entire life (Schalock, 2010). Of course, there have been a large number of definitions for this construct, from all of these we can mention some, aspects that are very important specially when we have to evaluate a person with disabilities, taking his/her real environment into account. Therefore, we can speak about adaptive behavior according to the person's age and cultural background, every individual can function in deep connection with his physical needs and his social participation, the ability of initiating and maintaining social relationships, the developmental nature of adaptive behavior including greater difficulties that come along with aging, adaptive behavior reflected in daily individual's acts (Bruininks, Thurlow \& Gilmore, 1987).

Social adaptive behaviors include interpersonal relationships, responsibility, self-esteem, tendency to believe too readily, compliance to rules, avoidance of victimization. These aspects will be followed across the present study as being influenced by emotional intelligence. There are also some ideas that we want to stress out concerning children's emotional and social competence, their behavior in the classroom or in some other setting and their ability to learn. What we mean is the way of being aware of the emotions (improving recognition, naming, understanding the causes of one's emotions), emotional control (supposing a good frustration tolerance, controlling anger, expressing anger in a suitable way, less isolation and anxiety, positive feelings about him/herself, school and family), the use of emotions in a productive way (more responsibility, concentration skills, less impulsivity, selfcontrol), empathy, approaching relationships.

Reuven BarOn (1992, apud Roco, 2004) established the components of emotional intelligence: the inner aspect (awareness of one's emotions, assertive behavior, selfrespect, independence), the interpersonal aspect (empathy, positive relationships, social responsibility), adaptability (problem solving, testing reality, flexibility), stress control (tolerance, control of impulses), general disposition (happiness, optimism).

\section{Adaptive behavior and emotional intelligence in children with hearing disabilities}

In the case of children with hearing disabilities, it seems there are no significant delays concerning socio-emotional compared to the hearing peers. Hearing disability does not strongly affect one's person ability to react to social stimuli and to produce major difficulties in the area of social skills (Rieffe \& Terwogt, 2006).

Norway University of Sciences and Technologies conducted a study in 2016 assuming that the loss of hearing could represent a threat for a smooth development of social competencies. Social skills have been compared for 14 children with mild bilateral or unilateral hearing loss and 21 children with moderate to severe loss and for 123 children with typical hearing, all aged 4-5 and all the children with hearing loss had hearing aids. Associations between social skills, vocabulary skills and the age of introducing the hearing aid. Results suggests that despite a limited effect on the development of the vocabulary, it is possible that early intervention could promote social skills development (Rieffe \& Terwogt, 2006).

The same researchers performed a study in order to establish possible correlations between developmental levels of social skills, vocabulary, the age of introducing the aids and parental education in three groups of typical children, children with moderate and mild hearing loss and children with severe hearing loss. The findings revealed that children with severe hearing loss showed similar levels of social skills with the ones of typical children, while children with moderate or mild hearing loss were appreciated with almost a standard deviation smaller than the typical children.

Finally, another study in this area suggests that children with severe hearing disabilities aged between 9 and 13 included in intervention programs succeeded to improve their abilities in solving social problems, mainly the understanding of the steps involved in interpersonal problems. Intervention was also a way in which children significantly improved their assertive behavior (Suárez, 2000).

When we speak about children with hearing disabilities, we raise some problems that have to get 
answers, one of them concerns communication. In the precise case of the Special Technological High School for Hearing Impaired in Cluj-Napoca, the most common communication method is sign language, along with lips reading for children with profound hearing disability and with adapted verbal language and of course, natural gesture, mimics.

Children with hearing disabilities succeed to realize an understanding based upon signifying some situations that they may observe, concrete, connected with immediate reality. But if the situation needs an understanding of complex, abstract aspects that cannot be observed directly they cannot perceive the essence of that situation. Therefore, the teachers have to find associations in order to facilitate understanding, mainly with an image and with the specific sign from the sign language alphabet. For a better understanding of a text, its associations with a representative image for the whole, along with signing the story are very useful tools. Dramas can also be used, cartoons, summaries of the images and of the interactions between images and words are helpful ways to make these children understand specially in older students.

For children with hearing disabilities, learning is about a mediation that the teacher is performing between the child and the world around him. It supposes using total communication, using all the available tools to transmit a message, so that this message is understood: verbal language, sign language, lips reading, mimics, gesture, facial expression.

As we mentioned before, our first aim for the study was to investigate the relationship between emotional intelligence and adaptive behavior in children with hearing disabilities, so necessary within the boarding school in which these children are staying during school time. And secondly, we aimed to establish a possible correlation between social adaptive skills, the degree of disability and the type of hearing aid. Therefore, we assumed that the higher level of emotional intelligence the children have, they will exhibit better social adaptive behavior. And secondly, there is no correlation between social adaptive skills, the degree of disability and the type of hearing aid.

\section{Results}

\subsection{Participants}

In this study there were 40 participants, students with ages range between 14 years and 20 years (an age average of 17.07 years, $23(57.5 \%)$ girls and $17(42.5 \%)$ boys, within the Special Technological High School for Hearing Impaired in Cluj-Napoca. These participants have been selected according to the following criteria: all of them had a neuro-sensitive hearing loss (profound, severe or moderate), they were students in the Special Technological High School for Hearing Impaired in Cluj-Napoca and they had no associated impairments.
Figure 1. The number of the participants and their age

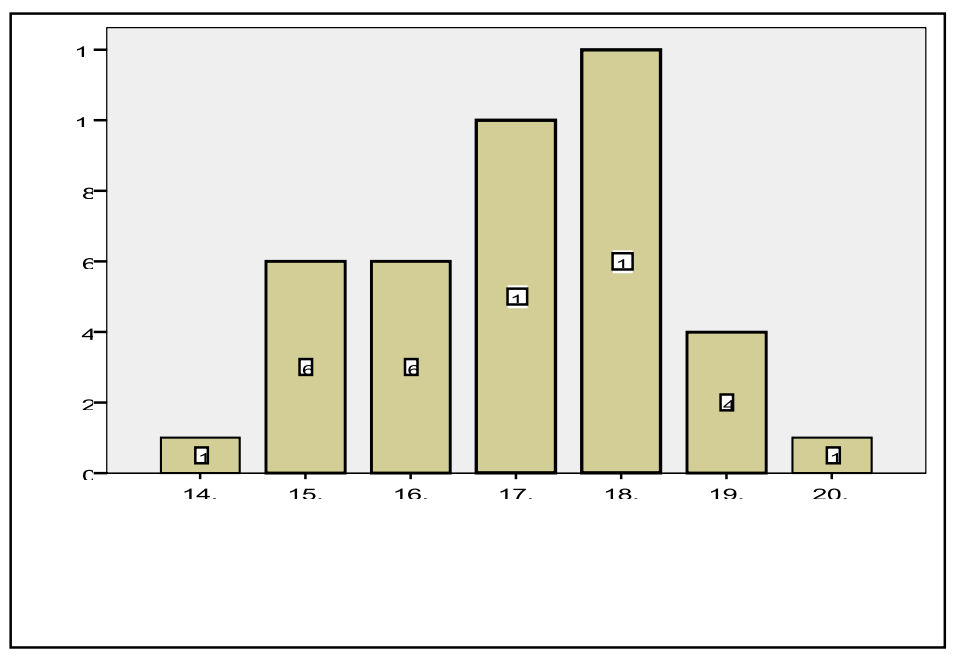

Age of the participants

$77.5 \%$ of the participants have normal hearing parents, $20 \%$ have both parents with hearing disabilities and $2.5 \%$ have families in which one parent is normal hearing and the other has hearing disabilities. Concerning other variables included in the study, $5 \%$ of the participants have moderate hearing disability, $17.5 \%$ have severe hearing disability and most of them, $77.5 \%$ have profound hearing disability. All the participants had the opportunity of an early intervention with the help of hearing aids; in the same time, they were included in different types of educational therapies and according to the specialists they were guided through the communication methods, the adaptations that were considered the best for each of them.

Figure 2. The degree of hearing loss

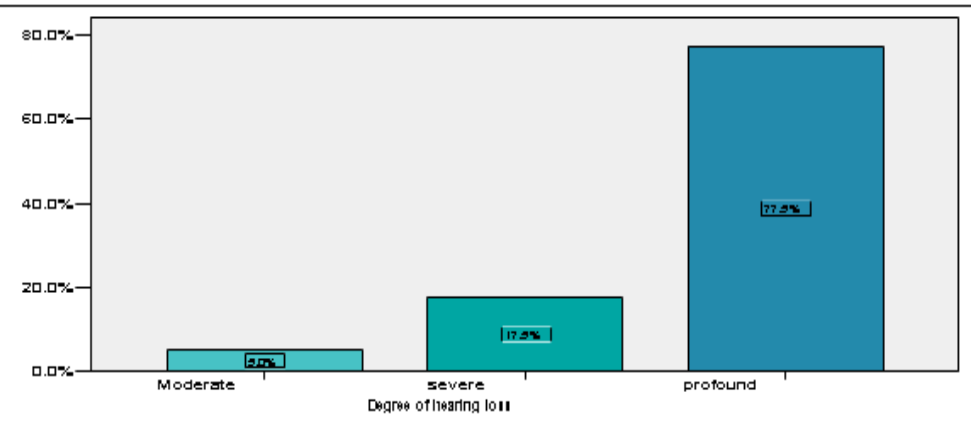

Concerning the type of hearing aids, $50 \%$ of the participants do not have any of these/have a non-functional cochlear implant, $7.5 \%$ have functional cochlear implant and $42.5 \%$ have a hearing aid which they wear.

The type of design in this study is a predictive nonexperimental one because it aims to establish if and in which measure emotional intelligence influences, predicts a successful social skill for children with hearing disabilities. We can therefore mention the variables of the 
study, the predictive one is emotional intelligence and the criterial one is the scholar social adaptive skills. For the second assumption, the study is correlational.

\subsection{Instruments}

\subsubsection{Adaptive Behavior Assessment SystemII (ABAS-II)}

ABAS-II (Harisson, Oakland, 2012) offers a valid measure of adaptive skills for persons until 89 years of age. It is a valuable instrument which evaluates the areas of adaptive skills mentioned in the Diagnostic and Statistical Manual of Mental Disorders 4th edition (DSM-V, American Psychiatric Association, 2013), American Psychiatry Association (APA, 2000), including the current directions of the American Association of Intellectual Disabilities (AAID) for the three main fields of the adaptive behavior (conceptual, social and practical).

As measured by ABAS-II, adaptive skills are defined as daily practical abilities needed for a person to function, to integrate in the environment, including the capacity of taking care independently of him or herself and the interaction with other people. In this study we used the form for teachers, with only one skills area, the one named "social" within the test, with 20 items measuring on a Likert scale the adaptive skills specific for school setting, more precisely personal relationships, responsibility, selfesteem, tendency to believe too readily, gullibility, respecting rules and norms and avoiding victimization.

The gross scores obtained are transformed, according to the tables, in scaled scores on a scale from 1 to 14,1 meaning a very low level and 14 the highest level.

\subsubsection{The Emotional Intelligence Test (EIT)}

The Emotional Intelligence Test was adapted by Rocco (2004, original version BarOn \& Goleman, 1992) consists in 10 questions presenting some situations (scenarios) a person can find herself in. The items refer to the identification of emotions and adaptability, empathy and involvement, inner motivation and hope, optimism/tenacity, accepting diversity/assertive democratic model, empathy for angry persons, anger control, anger management and calming strategies, manager qualities, ensuring comfort, empathy for persons with special needs and intuition, self-improvement, sustained work, development (Dewi et al., 2015).

For each participant there can be an exceptional score (more than 200), above the average score (150-200), average score (100-150), under the average (less than 100).

\section{Procedure}

This study respected the principles outlined in the current legislation on clinical investigation, and the Research Ethics Committee of the Babeș-Bolyai University approved it. Due to the situation created by the pandemic conditions and the on-line courses in schools, the EIT has been administrated on-line with an adapted version and a video material which was necessary for the transposition of the participation agreement, the summary of the test, the training concerning the way the items should be completed in the Romanian Sign Language.

The positive aspect of this method was the fact that each of the participants responded sincerely, without being influenced by their colleagues, as it happens frequently within collective testing situations.

On the other hand, the social skills area included in the form for teachers within the ABAS-II is filled in by the educator responsible for each classroom who is trained how to respond to all the items. In order to obtain the highest data accuracy, the educator will complete only two forms/day, for two children that is and the information will be checked also by other professionals working on a regular basis with the children to ensure the objectivity of the answers.

The scaled scores for all the participants were introduced in the program SPSS so that a value of the assumptions could result.

\section{Results}

Our first assumption was that the higher level of emotional intelligence the children have, they will exhibit better social adaptive behavior. Therefore, we wanted to see whether the social skills could be explained or influenced by emotional intelligence in children with hearing disabilities and for this we first verified the normality of the distribution for the predictor/the independent variable (emotional intelligence) as well as for the criteria/dependent variable (social skills). We used the Kolmogorov-Smirnov test, which compares the distributions of the scores for the sample with a normal distribution having the same average and standard deviation. As the result for this test is statistically insignificant for each variable, we concluded that the answers are normally distributed.

Table 1. Kolmogorov-Smirnov Test

\begin{tabular}{llll}
\hline & & $\begin{array}{l}\text { Emotional } \\
\text { intelligence }\end{array}$ & $\begin{array}{l}\text { Adaptive } \\
\text { skills } \\
\text { school }\end{array}$ \\
\hline $\mathrm{N}$ & Mean & 40 & 40 \\
$\begin{array}{l}\text { Normal } \\
\text { Parameters }\end{array}$ & 84.8750 & 7.1500 \\
& Std. Deviation & 31.03942 & 3.73857 \\
Most Extreme & Absolute & .163 & .140 \\
$\begin{array}{l}\text { Differences } \\
\text { Positive }\end{array}$ & .098 & .085 \\
$\begin{array}{l}\text { Kolmogorov- } \\
\text { Smirnov Z }\end{array}$ & Negative & .163 & .140 \\
$\begin{array}{l}\text { Asymp. Sig. (2- } \\
\text { tailed) }\end{array}$ & & 1.028 & .885 \\
\hline
\end{tabular}


Further on we verify the conditions that allows us to use the simple regression method in order to verify if there is high degree of prediction of the results for the EIT on the social skills. These refer to a normal distribution of the quantitative variables (Table 1), the relationship between the independent variable (emotional intelligence) and the dependent variable (social skills) has to be linear (Figure 3 ), the errors are normally distributed (Figure 4) and the avoidance of extreme cases and influent cases (Table 2).

Figure 3. The relationship between the predictor and the criteria (regression gradient)

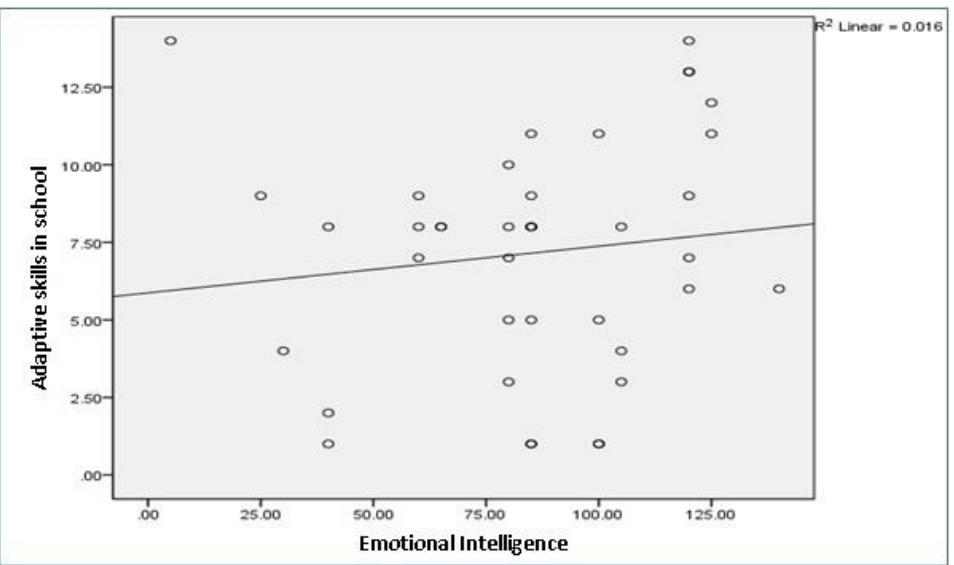

Figure 4. Error distribution

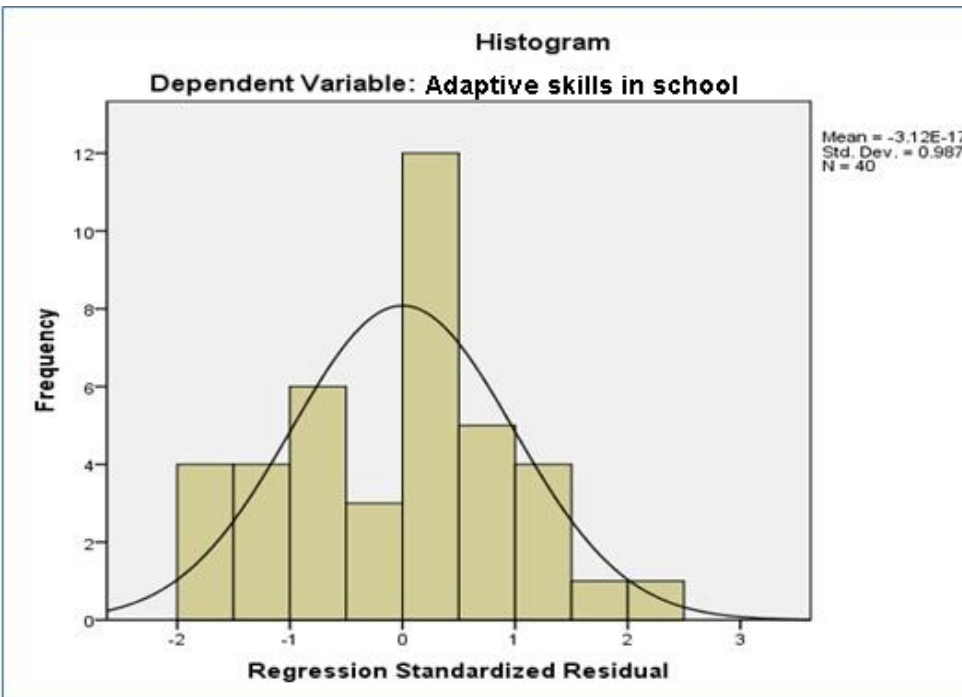

We can observe in Figure 3 that there is a linear relationship between the two variables and in Figure 4 we can see that the errors are normally distributed. If we analyze Table 2, the values Std. Residual, Stud. Residual and Cook's Distance, knowing that for more than $1 \%$ of the values of Std. Residual and Stud. Residual are between [-3, $3]$, the regression equation is not stable (Field, 2013). And as the minimum and maximum values in Table 2 are not overpassing this interval, we will consider that there are no extreme cases. In the same time, we notice that in Table 2 the maximum value for Cook's Distance is 0.69 (smaller than 1), which shows us that there are no influent cases. We can therefore conclude that all the conditions for the simple linear regression are fulfilled.

Table 2. Statistical data concerning errors

\begin{tabular}{|c|c|c|c|c|c|}
\hline & Minimum & Maximum & Mean & $\begin{array}{l}\text { Std. } \\
\text { Deviation }\end{array}$ & $\mathrm{N}$ \\
\hline $\begin{array}{l}\text { Predicted } \\
\text { Value }\end{array}$ & 5.9473 & 7.9800 & 7.1500 & .46735 & 40 \\
\hline $\begin{array}{l}\text { Std. } \\
\text { Predicted } \\
\text { Value }\end{array}$ & -2.573 & 1.776 & .000 & 1.000 & 40 \\
\hline $\begin{array}{l}\text { Standard } \\
\text { Error of } \\
\text { Predicted } \\
\text { Value }\end{array}$ & .594 & 1.659 & .805 & .244 & 40 \\
\hline $\begin{array}{l}\text { Adjusted } \\
\text { Predicted } \\
\text { Value }\end{array}$ & 3.9992 & 8.2145 & 7.1000 & .65601 & 40 \\
\hline Residual & -6.37773 & 8.05266 & .00000 & 3.70925 & 40 \\
\hline $\begin{array}{l}\text { Std. } \\
\text { Residual }\end{array}$ & -1.697 & 2.143 & .000 & .987 & 40 \\
\hline $\begin{array}{l}\text { Stud. } \\
\text { Residual }\end{array}$ & -1.724 & 2.388 & .006 & 1.022 & 40 \\
\hline $\begin{array}{l}\text { Deleted } \\
\text { Residual }\end{array}$ & -6.58237 & 10.00078 & .05002 & 3.98471 & 40 \\
\hline $\begin{array}{l}\text { Mahal. } \\
\text { Distance }\end{array}$ & .000 & 6.622 & .975 & 1.342 & 40 \\
\hline $\begin{array}{l}\text { Cook`s } \\
\text { Distance }\end{array}$ & .000 & .690 & .039 & .109 & 40 \\
\hline $\begin{array}{l}\text { Centered } \\
\text { Leverage } \\
\text { Value }\end{array}$ & .000 & .170 & .025 & .034 & 40 \\
\hline
\end{tabular}

Tables 3 and 4 include the results of the simple linear regression analysis, what we may notice from these data is the fact that the results are statistically significant $F(1.39)$ $=0.603$, Sig. $=0.442$ and the adjusted value of the determination quotient is 0.016 , meaning that just $1.6 \%$ of the emotional intelligence variance could explain the social skills one.

Table 3. Results of the regression analysis concerning the social skills based on the scores in emotional intelligence

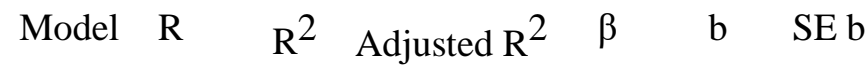

\begin{tabular}{lllllll}
\hline 1 & .125 & .016 & -.010 & .125 & .015 & .019
\end{tabular}

Table 4. Results in testing the significance of the regression line emotional intelligence-social skills

\begin{tabular}{lccccc}
\hline Model & $\begin{array}{c}\text { Sum of } \\
\text { Squares }\end{array}$ & df. & $\begin{array}{c}\text { Mean } \\
\text { Square }\end{array}$ & F & Sig. \\
1 & 8.518 & 1 & 8.518 & .603 & $.442^{\mathrm{a}}$ \\
Regression & & & & & \\
Residual & 536.582 & 38 & 14.121 & & \\
\multicolumn{1}{c}{ Total } & 545.100 & 39 & & & \\
\hline
\end{tabular}


Therefore, we can conclude that the first assumption is not confirmed, that means emotional intelligence is not a predictor for the social skills in children with hearing disabilities.

Concerning the second assumption which refers to the absence of any correlation between social skills and the degree of hearing loss and the type of hearing aid (prothesis, functional implant, non-functional implant or not wearing the prothesis) in children with hearing disabilities. First of all, we verified the distribution for the involved variable to see if this a normal one, through the Kolmogorov-Smirnov test (Table 5). The test compares the distribution of scores for the sample with a normal distribution with the same mean and standard deviation. Since the result for this test is statistically significant for variables degree of hearing loss and type of hearing aid, we can conclude that the answers are not normally distributed for these variables.

Table 5. Kolmogorov-Smirnov test. Comparison of the distribution of scores for the sample with a normal distribution with the same mean and standard deviation

\begin{tabular}{lrrr}
\hline & \multicolumn{1}{l}{$\begin{array}{l}\text { Adaptive } \\
\text { skills in } \\
\text { school }\end{array}$} & $\begin{array}{l}\text { Degree of } \\
\text { hearing } \\
\text { disability }\end{array}$ & $\begin{array}{l}\text { Type of } \\
\text { hearing } \\
\text { aid }\end{array}$ \\
\hline $\mathrm{N}$ & \multicolumn{4}{c}{40} & 40 & 40 \\
Normal & 7.1500 & 3.7250 & 1.9250 \\
$\begin{array}{l}\text { Parameters } \\
\text { Mean }\end{array}$ & & & \\
$\begin{array}{l}\text { Std. Deviation } \\
\text { Most Extreme }\end{array}$ & 3.73857 & .64001 & .97106 \\
$\begin{array}{l}\text { Differences } \\
\text { Absolute }\end{array}$ & .140 & .466 & .330 \\
$\begin{array}{l}\text { Positive } \\
\text { Negative }\end{array}$ & & & \\
Kolmogorov- & .085 & .334 & .330 \\
Smirnov Z & .885 & -.466 & -.291 \\
\hline
\end{tabular}

Since two variables are not normally distributed and ordinal, to verify the correlation between social skills, the degree of hearing loss and the type of hearing aid, we wanted to find out the Spearman correlation quotient (Table $6)$.

Table 6. Spearman correlations for adaptive skills, degree of hearing loss and type of hearing aid

\section{Correlations}

\begin{tabular}{|c|c|c|c|}
\hline & $\begin{array}{l}\text { Adaptive } \\
\text { skills in } \\
\text { school }\end{array}$ & $\begin{array}{l}\text { Degree } \\
\text { of } \\
\text { hearing } \\
\text { loss }\end{array}$ & $\begin{array}{l}\text { Type of } \\
\text { hearing } \\
\text { aid }\end{array}$ \\
\hline $\begin{array}{l}\text { Spearman`s rho } \\
\text { Adaptive skills in } \\
\text { school Correlation } \\
\text { Coefficient }\end{array}$ & 1.000 & .155 & .066 \\
\hline Sig. (2-tailed) & & .341 & .684 \\
\hline
\end{tabular}

\section{$\mathrm{N}$}

40

40

40

.155

1.000

$-.188$

Degree of hearing loss

Correlation

Coefficient

Sig. (2-tailed)

40

N

40

40

40

.066

$-.188$

1.000

Type of hearing aid

Correlation

Coefficient

Sig. (2-tailed)

$\begin{array}{ll}.684 & .246 \\ 40 & 40\end{array}$

40

$\mathrm{N}$

As we can observe from Table 6, there is no statistically significant correlation between social skills and the degree of hearing loss, $\rho(38)=0.155$, Sig. $=0.341$ and in the same time there is no statistically significant correlation between social skills and the type of the hearing aid $\rho(38)=0.066$, Sig. $=0.684$.

Since we have obtained these results, we can conclude that the second assumption we stated is confirmed and therefore there is a correlation between social skills and the degree of hearing loss and the type of hearing aid (prothesis, functional implant, non-functional implant or not wearing the prothesis) in childrenwith hearing disabilities.

\section{Discussions and conclusions}

The idea of the present study came from our concerns regarding the way in which children with hearing disabilities succeed to adapt in different settings and of course, mainly in school because it is the environment where we have the opportunity to observe and to analyze all the aspects that go along with it. It seemed of great interest for us to see if we could realize some connections between some variables related to the child himself, that is emotional intelligence and adaptive skills, and on the other hand, the degree of hearing loss and the type of hearing aid. And of great importance is also the way in which the child gets related to the teachers, to his peers in school and his relationships within his family.

We consider that both emotional intelligence and social adaptive skills in school have a greater chance to develop in an adequate way if teachers show empathy, respect, trust, an active involvement in all their activities, even if these are successful or if they fail from time to time. Studies suggest that sociodemographic variables; such as access to hearing assessment and speech services, time of intervention, presence of hearing impaired family member, preferred communication method of family, preferred communication method of the participants regardless of 
their hearing loss play important roles in developing the adaptive emotional abilities of children with hearing disabilities and that hearing disability itself is not the only reason of lower performance of this category of children (Akram \& Hameed, 2014).

On the other hand, other studies, such as the one conducted by De Giacomo (2013) investigating cognitive skills, adaptive behaviors, social and emotional skills in children with cochlear implants showed that there were no significant differences with the results of children with normal hearing, perhaps only small differences concerning emotional problems and relationships with peers.

Of course, as seen in our study we did not intend to investigate all the relationships between all the variables we mentioned above, this could be one of the limitations. One other limitation is related to the number of the participants, so we can say that the results we obtained concern this group of participants only and not all the factors that could contribute to the extent of their development neither in the emotional intelligence area, nor in the one of adaptive skills were considered.

Nevertheless, it is well known that life skills training is effective in enhancing the self-esteem of children with hearing disabilities and some of the social skills that children may develop are related to making friends, initiating conversation, joining social groups, all of these can be taught by modeling, social skills exercises, stories, dramatherapy (Vernosfaderani, 2013).

When we speak about children with hearing disabilities, the message they perceive is, most of the time shortened, partially perceived, the child is rebuilding it according to the context, to his knowledge, to his intelligence. That is the reason why there are many misunderstandings, situations of bad interpretation, incorrect meanings which can produce challenging behaviors, out of the context, not adapted to the situation, which can create confusion for the child with hearing disabilities as well as for the normally hearing person.

The participants who receive intervention in pre-lingual period in the form of any amplification, cochlear implantation, speech training, have higher levels of emotional abilities and this is the case also for the participants we included in our study. The results are also consistent with the findings of Smith et al. (2014) who asserted the important role of early intervention in the development of cognitive abilities of children with hearing impairments. Early intervention is possible on the basis of early assessment and diagnosis. The children with hearing disabilities who received language oriented early intervention programs showed better social emotional adjustment as compared to peers who were not involved in intervention programs (Calderon \& Greenberg, 1993) and this is also a possible reason for our results. For sure, further research is needed with larger samples in different settings and considering the interactions between more variables in order to confirm some of the findings.

Authors note: The authors have equal contributions to this article

Cristina Bălaş-Baconschi is Lecturer at the Special Education Department, Faculty of Psychology and Educational Sciences, with $\mathrm{PhD}$ in Psychology. Her research interests include autistic spectrum disorders, social and emotional disorders, intellectual disabilities, arttherapy applied for persons with different disabilities, social psychology.

Lucreția-Delia Dobrican is Professor-educator at the Special Technological High School for Hearing Impaired Cluj-Napoca.

\section{References}

Akram, B., Hameed, A. (2014).Adaptive Emotional Abilities of Adolescents with Hearing Impairment. Pakistan Journal of Psychological Research, 29 (1), 103-123.

American Psychiatric Association (2013). Diagnostic and Statistical Manual of Mental Disorders, Fifth Edition, DSM-5, Washington DC, American Psychiatric Publishing.

Bruininks, R. H., Thurlow, M., \& Gilmore, C. J. (1987). Adaptive behavior and mental retardation. Journal of Special Education, 21, 69-88.

Calderon, R., \& Greenberg, M. (1993). Considerations in the adaptation of families with school-aged deaf children. In M. Marschark \& M.D. Clark, (Eds). Psychological perspectives on deafness, 27-48. Hillsdale, NJ, USA: LEA.

Campbell, S.B. (1995). Behavior problem in preschool children: A review of recent research.The Journal of Child Psychology and Psychiatry, 36, 113-149.

Conners-Burrow, N. A., Patrick, T., Kyzer, A., McKelvey, L. (2017). A Preliminary Evaluation of Reach: Training Early Childhood Teachers to Support Children's Social and Emotional Development, Early Childhood Education Journal, 45 (2), 187-199.

De Giacomo, A., Craig, F., D'Elia, A., Giagnotti. F., Matera. E., Quaranta, N. (2013). Children with cochlear implants: Cognitive skills, adaptive behaviors, social and emotional skills. International Journal of Pediatric Otorhinolaryngology, 77, 1975-1979.

Dewi, Z.L., Halim, M.S., Derksen, J. (2015). The BarOn Emotional Quotient Inventory (EQ-i): Development and Psychometric Adaptation in Bahasa Indonesia, Journal of Psychological Sciences, ISSN 2379-012, 1 (2), 47-61.

Dunlap, G., Powell, D., Fox, L. (2006).Prevention and Intervention for the Challenging Behaviors of Toddlers 
and Preschoolers, Infants \& Young Children, 9 (1), 2535.

Goleman, D. (2019).Inteligența emoțională, București: Editura Curtea Veche.

Field, A. (2013) Discovering Statistics Using IBM SPSS Statistics, SAGE.

Harison P.L. și Oakland T. (2012). ABAS II Sistemul de evaluare a comportamentului adaptativ - Manual. Ediția a doua. București (traducere și adaptare în limba română de Iliescu D. şi Varcellino D.).

Laugen, N., Jacobsen, K., Rieffe, C. \& Wichstrøm, L. (2017) Social skills in preschool children with unilateral and mild bilateral hearing loss, Deafness \& Education International, $19(2), \quad 54-62, \quad$ DOI: 10.1080/14643154.2017.1344366.

Pleșca, M. (2016). Influența inteligenţei emoţionale asupra performanţei academice în Revista de știinţe socioumane nr. 1(32). 53-58.

Racu, I. Domniţa, N. (2015) Profilul de personalitate al preadolescentului cu nivel ridicat de inteligență emoțională În Revista de Psihologie. Pedagogie Specială. Asistenţă Socială, nr. 3(40), 122-126.

Rieffe, C. \& Terwogt, M. M., (2006). Anger communication in deaf children. Cognition and Emotion, 20 (8), 1261-1273.
Roco, M. (2004). Creativitate și inteligență emotională. Iași: Polirom.

Roșan, A. (coord.) (2015). Psihopedagogie specială Modele de evaluare și intervenție. Iași: Polirom.

Schalock, R. L., Borthwick-Duffy, S. A., Bradley,V. J., Buntinx, W. H. E., Coulter, D. L., Craig, E. M.,Yeager, M. H. (2010). Intellectual disability: Diagnosis, classification, and systems of supports $\left(11^{\text {th }}\right.$ ed.). Washington, DC: American Association on Intellectual and Developmental Disabilities.

Smith, R.J.H., Shearer, A.E., Van Camp G., \& Heidalbrand, M.S. (2014). Deafness and hereditary: Hearing loss overview. Retrieved from www.ncbi.nlm.nih.gov/books/NBK 1434.

Suárez M. (2000) Promoting social competence in deaf students: the effect of an intervention program. J Deaf Stud Deaf Educ., 5(4), 323-333. doi:10.1093/deafed/5.4.323.

Vernosfaderani, M. (2014) The Effectiveness of Life Skills Training on Enhancing the Self-Esteem of Hearing Impaired Students in Inclusive Schools, Open Journal of Medical Psychology, 3, 94-99. 